\title{
FAIR REPRESENTATION IN CANADA: ALL FOR ONE AND ONE FOR ALL

\author{
DAVID SURMON*
}

\begin{abstract}
The author discusses the development, procedural requirements, and formulations of a union's duty of fair representation. He argues that the fair representation standard of care has been inconsistently applied in Canada and suggests a consistent approach which would be efficient, in terms of preventing unmeritorious litigation, promoting harmonious labor relations and protecting the interests of union members.
\end{abstract}

\section{INTRODUCTION}

Section 136 of the Canada Labour Code provides that a certified trade union has "exclusive authority to bargain collectively on behalf of the employees in the bargaining unit."1 As a statutorily created employee agent, a union receives the authority to negotiate and administer the grievance-arbitration provisions of the collective agreement. Undoubtedly, conferring such powers on unions has produced a significant countervailing force to what was once virtually complete control over the workplace by the employer. However, vesting the union with exclusive control over the collective agreement invites abuse and exploitation of the minority. At common law, an employee may bring an action on the basis of breach of contract. ${ }^{2}$ However, the problems associated with a court action (for example, cost and cause of action) have made recourse to the courts impractical for the ordinary employee in disagreement with his union. ${ }^{3}$

A statutory duty of fair representation has now been imposed on unions in Canada ${ }^{4}$ to counter the union's unrestricted authority and power, thereby ensuring a representative is accountable to employees who by law or contract can no longer effectively present grievances by themselves. As a result of the union's duty to fairly represent members of the bargaining unit, the courts and labour boards have struggled to balance the rights of the individual employee against conflicting group interests.

This paper will focus on the union's duty of fair representation as it relates to arbitration in Canada. The fair representation standard of care has often been inconsistent and confusing. A seemingly piecemeal adoption of American precedent in this area has resulted in an inefficient system for resolving industrial grievances in Canada. A preferred approach, whereby the statutory requirements of the fair representation

* A recent graduate of the Faculty of Law, University of Western Ontario.

1. R.S.C. 1970 c. L-1 s. 116; it should be noted that s. 132 of the Code protects the employee's right to present his personal grievance to his employer.

2. Orchard v. Tunney (1957) 8 D.L.R. (2d) 273 (S.C.C.); H.W. Arthurs, D.D. Carter, and H.J. Glasbeek, Labour Law and Industrial Relations in Canada (1981) at 139-140.

3. David C. McPhillips, "Duty of Fair Representation" (1981) 36 Relations Industrielles 803 at 824.

4. See Appendix A infra; from the varying standards it is apparent that there is not a uniform definition of the duty across Canada; while these differences will be discussed below, it is enough to say here that common principles are found throughout the jurisdictions and therefore both provincial and federal case law will be employed in the analysis that follows, with emphasis upon federal jurisprudence. 
duty would be narrowly construed, will be suggested. This paper will examine the development, procedural requirements, and formulations of the union's duty of fair representation.

\section{DEVELOPMENT OF THE FAIR REPRESENTATION DUTY}

In dealing with the worker's rights against an employer, a preliminary question may be why the union's duty of fair representation is a matter of concern. The answer lies in the nature of the rights of the employee as against the employer and the structure of grievance procedures in most collective agreements. As a member of a union, a worker's contractual rights arise from collective bargaining agreements negotiated by unions. In most agreements there is a multi-step grievance procedure ending in arbitration which is final and binding on all parties. In most Canadian jurisdictions such a procedure is required by statute. Further, the collective agreement must provide that the grievance procedures are the exclusive method for resolving disputes as to the interpretation of the agreement, and that the union, not the individual worker, has the power to decide how far the grievance should be pursued. ${ }^{5}$ Thus, should the union decide not to arbitrate the grievance, the grievor has no contractual right to demand arbitration. ${ }^{6}$ When it appears legitimate grievances have not been properly processed, the conduct of the union itself comes into question.

The duty of fair representation was developed by American courts in the 1940's. In its landmark decision, Steele v. Louisville and Nashville Railroad, ${ }^{7}$ the United States Supreme Court ruled that the duty of fair representation is an obligation inherent in the union's statutory grant of exclusive representative status. ${ }^{8}$ The decision was based on the general premise that the "exercise of a granted power to act on behalf of others involves the assumption toward them of a duty to exercise the power in their interest and behalf." " While the duty was initially developed to guard against racial discrimination by union officials in the negotiation of collective agreements, it has been expanded to cover the processing of employee grievances ${ }^{10}$ - whether or not the employee in the bargaining unit was a member of the union. ${ }^{11}$

5. Steven Savner, "The Application and Meaning of the Duty of Fair Representation" (1978) 13 Clearinghouse Review 13.

6. Rayonier Canada (B.C.) Ltd. [1975] 2 Can. L.R.B.R. 196; U.A.W., Local 1459 [1979] O.L.R.B. Rep. 913; again, practical barriers would discourage many complainants from bringing an action against the union for breach of contract in the courts.

7. (1944) 323 U.S. 192.

8. Section 9(a) of the National Labour Relations Act 61 State 136, 29 U.S.C.A. s. 151 was used as the basis for the duty: "Representatives designated or selected for the purpose of collective bargaining by the majority of employees in a unit appropriate for such purposes, shall be the exclusive representative of all employees in such unit for the purpose of collective bargaining in respect to rates of pay, wages, hours of employment, or other conditions of employment."

9. Supran. 7 at 202.

10. E.g. Ford Motor Co. v. Huffman (1953) 345 U.S. 330 (U.S.S.C.); Miranda Fuel Co. (1962) 140 N.L.R.B. 181.

11. Dillardv. Cheasapeake \& O. Ry. 199F. 2d. 948 (4th Cir., 1952). 
In its 1967 decision Vaca v. Sipes, ${ }^{12}$ the United States Supreme Court finally expressed the union's duty in the form of a positive test: ${ }^{13}$

A breach of the statutory duty of fair representation occurs only when a union's conduct toward a member of the collective bargaining unit is arbitrary, discriminatory, or in bad faith.

There is substantial academic support for the proposition that the American fair representation duty should be further extended to apply to a wider range of union conduct. ${ }^{14}$ Unsatisfied grievors have seized upon the general applicability of the principles set out in the decisions above, making the union's duty of fair representation amongst the most controversial and litigated areas in American labour law. ${ }^{15}$ While the utility of such litigation will be examined below, it is enough to say here that broadly defining the union's duty of fair representation has had a farreaching impact on the American collective bargaining system. ${ }^{16}$

In Canada, the development of a fair representation duty has been a rather peculiar one. Enacting a duty was first recommended in 1968 by the Woods Task Force Report:

329. Another troublesome issue concerns the relative rights of the collectivity and of individuals in the negotiation and administration of a collective agreement. The problem can best be illustrated in relation to the individual member's right of access to the grievance procedure and to arbitration. Normally such access is controlled by the union, and this is as it must be if collective bargaining is not to be undermined. Yet the union should be expected to exercise this discretionary power in a fair and impartial manner if it is not to have arbitrary control over its members. This suggests that a union should be able to show that it acts in good faith whenever it chooses not to pursue a member's grievance or to pursue another contrary to his interest. This must be the limit to any concept of fair representation if responsible collective decision making within and between union management is not to be jeopardized. ${ }^{17}$ (emphasis added.)

The Woods recommendation was passed over in the new 1973 Federal Labour Code. However, on June 1, 1978 the recommendation was proclaimed in force, as expressed by s. 136.1 of the Federal Code. While some jurisdictions were quicker to recognize a duty of fair representation, ${ }^{18}$ for the most part, there was a cautious response to following the American lead of a generally applicable duty. ${ }^{19}$

12. (1967) 386 U.S. 171.

13. Id. at 190.

14. E.g. P.H. Tobias, "A Plea for the Wrongfully Discharged Employee Abandoned by His Union" (1972) 41 U. Cinn L. Rev. 55; B.R. Naar, "The Exhaustion of Intra-Union Procedures in Duty of Fair Representation Cases" (1979) 32 Rutgers L.R. 520 at 540-2; Jeffery L. Ulman, "Exhaustion of Internal Union Appeals Procedures as a Prerequisite to Individual Section 301 Suits"' (1982) 46 Albany L.R. 1069.

15. Frederic C. Leffler, "Piercing the Duty of Fair Representation" (1979) 1 U. of Illinois L.F. 35.

16. Supra n. 2 Labour Law and Industrial Relations in Canada at 139-140; Solly and CWC [1981] 2 Can. L.R.B.R. 245 at 254.

17. Woods Task Force Report (Canadian Industrial Relations, 1968) p. 104.

18. Fisher v. Pemberton (1969), 8 D.L.R. (3d) 521 (B.C.S.C.) at 540-41; Labour Code of British Columbia, S.B.C. 1973, c. 122, s. 7; also it should be noted here that in situations where the union assumes a position adverse to the employee's interests at arbitration, it has been held that the employee is entitled to be personally represented: see $\operatorname{Re}$ Hoogendoorn (1968) 65 D.L.R. (2d) 641 (S.C.C.) and Re Bradley [1967] 2 O.R. 311 (Ont. C.A.).

19. Hasen Ergen [1979] 1 C.L.S. 6.2514 (C.L.R.B.); it is of further interest to note that only the federal jurisdiction assumed the American lead in Vaca of a positively-worded standard (see Appendix A). While some technical differences will be noted infra, the intent of the various sections is sufficiently similar so as to be treated together for purposes of this paper. 
The concern for limiting the union's standard of care in the Wood's Report $^{20}$ demonstrates a friction between the principle of union exclusivity and the need to protect the individual employee from union misconduct. Support for narrowly defining the union's standard of care in Canada can be gleaned from an examination of the underpinnings of the fair representation duty.

Prior to the establishment of the fair representation duty in the 1950's in the United States, the principle of union exclusivity was jealously guarded. Union solidarity had begun to produce real steps forward for the working class. On the other hand, this period would prove to be a turbulent one for individual rights under the collective agreement. The early American cases alleging unfair representation typically involved blatantly oppressive conduct towards a bargaining unit member. ${ }^{21}$ The imposition of the fair representation duty demonstrated that there was a limit to the principle of union exclusivity. The point to be made, however, is that the rigorous standard needed to combat the extremes of union discrimination in the United States in the mid-1900's has never been the type of standard required in Canada. Due to Canada's relatively mild racial conflicts, and relatively weak union power, the need for protection of individual rights under the collective agreement is simply not as strong in Canada today as it was (and perhaps still is) in the United States. The American practice of broadly construing the union's duty is not only uncalled for in Canada, it would be counterproductive: by undercutting the union's exclusive bargaining agent status, the management-union relationship is weakened, resulting in commercial instability. Therefore, a narrowly defined fair representation duty would protect the employer's interest by ensuring the union's exclusive bargaining status; and more fundamentally, would allow for the free operation of the marketplace without undue interference from individual employees using the protective measures of the duty to, in effect, compel arbitration of a grievance that is without merit.

\section{APPLICABILITY OF THE DUTY}

\section{A. SCOPE}

To put the duty of fair representation in perspective, several matters require consideration. The duty controls the actions of the trade union in the negotiation of a contract, and in the administration of the contract. With regard to the former, it is typically alleged that the union has negotiated a particular clause in the settlement of the collective agreement that is discriminatory or unfair towards certain members of the bargaining unit. 22

20. This concern has been recently reiterated, see: Cloutier and Cartage Union [1981] 2 Can. LRBR 335; Elliston v. U.S.W.A., [1982] 2 Can. LRBR 24 ].

21. For example, racial discrimination in Steele v. Louisville \& Nashville Railroad Co. supra n. 7 , where a negotiated seniority clause was struck down because it placed all black employees at the bottom of the list.

22. Steele v. Louisville \& Nashville Railroad Co. supra n. 7; Group of Seagrams Employees v. Distillery, Brewery, Winery, Soft Drink and Allied Workers' Union, Local 604 and B.C. Distillery Company Limited (1978] I Can. LRBR 375 (B.C.L.R.B.). 
With regard to conflicts during the administration of the contract, the distinction must be drawn between internal union appeal procedures and contract grievance procedures. Contractual grievance procedures are methods for resolving disputes arising within the employment relationship. They are bargained for between the union and management and incorporated into the collective agreement. ${ }^{23}$ Generally, it is only with regard to such contractual grievance procedures that the duty of fair representation applies.

On the other hand, internal union procedures are mechanisms established by union constitutions which are normally adopted in order to provide sanctions against internal union misconduct. ${ }^{24}$ With one exception, ${ }^{25}$ Canadian statutes appear to give labour relations boards the jurisdiction to review the internal affairs of unions. ${ }^{26}$ In practice however, the duty has not been used by the boards to scrutinize the conduct of internal affairs.

In $R e$ Manoni and L.I.U.N.A. Loc 527,27 the complainant alleged that, amongst other things, union of ficials had conducted an election contrary to the union constitution. This alleged misconduct was argued to be in breach of the union's duty of fair representation. The Board held that such internal affairs of union were outside the scope of s. 68 of the O.L.R.A., and therefore "recourse must be made by an aggrieved member to the governing rules provided under the constitution for relief."28 It is well established that the union's internal rules will be supervised by the courts to see that they are implemented fairly and impartially. ${ }^{29}$

However, it is important to note that in exceptional cases ${ }^{30}$ boards will use the fair representation duty to scrutinize internal union affairs where they "relate directly to and form part of the bargained relationship between the employer and union." 31 Thus, unless the union's misconduct directly affects the employment status of a member of the bargaining

23. Claytonv. U.A.W. (1981) 101 S. Ct. 2088 at 2095.

24. Id. at 2099.

25. Section 138 of the Alberta Labour Relations Act (see Appendix A) explicitly avoids the Board's jurisdiction over internal affairs of unions by restricting the fair representation duty to matters involving the employee's rights under the collective agreement.

26. See Appendix A.

27. [1982] I Can. LRBR 347.

28. Id. at 350; similarly because the alleged prejudice must be to the employee at the hands of the employer, the duty does not protect a union business agent against unfair dismissal by the union: Re Roberts [1974] 1 Can. LRBR 201; further, it has been held that the duty does not extend to include a review of events which occurred prior to certification since the duty applies only to employees in an appropriate bargaining unit: Joyce, Harvey and Halverson and Vancouver Reg. Employees' Union [1980] I Can. LRBR 509 (B.C.L.R.B.).

29. See Roberts v. Operative Plasters and CMIA, Local 48 [1974] I Can. LRBR 201.

30. Again, the Alberta boards which have their jurisdiction expressly limited to reviewing individual rights under the collective agreement.

31. Lochner v. CBRT (1979) 79 CLLC 16,209 (C.L.R.B.); similarly, it has been held s. 68 of the O.L.R.A. applies to not only grievance processing, but the "general employment interests" of the bargaining unit members: Gain and Smith v. Loc. 1565, Int'l Brotherhood of Electrical Workers [1979] 3 Can. LRBR 205 (OLRB) at 214; and s. 7 of the B.C.L.R.A. has been used to scrutinize internal af fairs of the union where they arbitrarily discriminate against an employee: Vancouver General Hospital [1978] 2 CLRBR 508. 
unit, the union's internal affairs are outside the scope of the fair representation duty.

Because the union has the power to bind every employee in the bargaining unit, its duty is to act fairly on behalf of not only union members but also non-members who are represented by the union for purposes of collective bargaining. ${ }^{32}$ If the collective agreement stipulates terms by which new employees will be hired or promoted into the bargaining unit, the applicant will have standing to complain of discrimination..$^{33}$ Further, the fair representation duty extends to members in arrears of dues and employees denied, suspended, or expelled from union membership. ${ }^{34}$ Similarly, it has been held that the union's duty towards an employee in respect of a grievance does not cease because that person ceases to be employed..$^{35}$

In Elliston v. U.S.W.A., ${ }^{36}$ the Board had to consider a collective agreement which purported to exclude a probationary employees' right not to be "unfairly" dismissed. The issue then became whether the duty of fair representation extended to such probationary employees. The Board held that the exclusionary clause was invalid because it denied probationary employees statutorily prescribed recourse ${ }^{37}$ to the grievance procedure as a means of enforcing the rights under the collective agreement, of all employees in the unit to be dismissed for just cause ${ }^{38}$ However the Board compromised this position by stating that the collective agreement could provide for a particular standard of review for certain categories of employees. In such cases, the arbitrator's role would be "reduced", but would still serve as a guard against discriminatory or arbitrary treatment.

Elliston is a difficult case. It would seem the Board was concerned with following the pattern set by previous decisions which narrowly construed the fair representation duty to be imposed on the union. ${ }^{39}$ On the other hand, the Board recognized the well established principle that all employees within the bargaining unit were entitled to union representation..$^{40}$ However, the practical consequences of the decision - referring the case back to the union to be considered on its merits - may prove to make the complainant's victory here a hollow one.

First, the union in Elliston could make a cursory investigation of the complaint and decide to drop the case short of arbitration, leaving the grievor without remedy. This would seem to be a likely result since it is

32. Re Teamsters Union Loc. 933 and Massicotte (1982) 134 D.L.R. (3d) 385 (S.C.C.); affg. 119 D.L.R. (3d) 193 (Fed. C.A.); affg. (1980) 80 C.L.L.C. 16,014 (C.L.R.B.).

33. Dillard supra n. 11; Len Lamour [1980] 3 Can. LRBR 407.

34. Supra n. 31, Lochner at 504.

35. Huggins v. Railway Workers [1980] 1 Can. LRBR 364.

36. [1982] 2 Can. LRBR 241.

37. Via s. 154 and s. 155 of the Canada Labour Code, see supra n. 36 Elliston at 254.

38. For a similar holding with respect to the rights of part-time employees, see Massicotte v. I.B.T. (1980) 80 CLLC 16,014 .

39. Supran. 36, Elliston at 259-60.

40. See supra n. 28; and more particularly, Cassiar Asbestos Corporation [1975] I Can. LRBR 212 at 216 where it stated: ". . . the parties here could not create the status of probation in their agreement, and then exclude disputes about its operation from arbitration, the method they have adopted to settle disputes arising under the collective agreement." 
obvious the union feels no loyalty to the probationary employee. Second, if the union decided it would be safer to take the case to arbitration, it could present the case in a subtly unconvincing manner and likely lose the case - the result desired by both employer and union. The "reduced" role of the arbitrator referred to in Ellison would make such a result all the more likely. The unfortunate consequences of such a scenario are the wasted resources of the union and employer and the unnecessary burden on the arbitration system. ${ }^{41}$ In any event, it can be concluded that if an employee is within the bargaining unit he will have standing to complain of a breach of the union's duty to fairly represent him.

\section{B. FORUM}

Both the labour relations boards and the courts may be involved in deciding whether fair representation has been denied. It is generally accepted that labour boards are best situated to decide fair representation cases. ${ }^{42}$ It would seem that the intention of the legislatures, ${ }^{43}$ as well as of the parties to a collective agreement, is to keep the administration of the agreement in the hands of those parties. ${ }^{44}$ Underlying this view is "a belief and expectation that those most knowledgeable with the collective system could best reshape practices to integrate [the duty] without doing irreparable harm to the fundamental collective bargaining system." 45

It is submitted that the role of the court should be reserved to considering the viability of argument presented to the labour board. The reviewing court would act as a watchdog over board decisions and would also enhance the development of consistent jurisprudence. Additionally, assigning the court the role of a reviewing body would recognize the need for sensitivity to the specialized subject matter characterized by the particular customs and practices of industrial relations. ${ }^{46}$ Finally, courts are limited to awarding monetary damages, ${ }^{47}$ which may be of little consolation to the wrongfully dismissed employee.

On balance, it would seem most desirable to have the better-equipped labour boards decide the fair representation question, subject to review by the courts.

41. The cost factor will be discussed in further depth infra.

42. For a view that the cases should be assigned to other non-judicial bodies, see David $\mathbf{C}$. McPhillips, "Duty of Fair Representation" supra n. 3.

43. E.g. by granting the unions status as exclusive bargaining agent of the employee: seen. 1 .

44. E.g. Republic Steel Corp. v. Maddox (1965) 379 U.S. 650 (U.S.S.C.); Donald Gebbie and J. Longmoorev. Ford Motor Co. of Canada [1973] OLRB Rep. 519.

45. Samperi and CALFAA [1982] 2 Can. LRBR 207 at 211, the same view has been expressed by the courts: ". . . we are concerned with the subtleties of a union's statutory duty to faithfully represent employees in the unit ... and the bounds of the reciprocal duties involved in the relationship between the union and the employee. In my opinion, this is precisely and especially the kind of judgment that Congress intended to entrust to the board ...": Fortas J. in Vaca v. Sipes supra n. 12 at 202; and similarly in Teamsters v. Missicotte (1982) 134 D.L.R. (3d) 385 (S.C.C.) at $391-92$.

46. B.L. Adell, "The Duty of Fair Representation" (1970) 25 Relations Industrielles 602.

47. Wayne Maclntyre, “Individual Rights and the Collective Bargaining Process' (1974-76) 40 Sask. L.R. 269 at 280. 


\section{THE GRIEVANCE PROCEDURE}

Resolving a dispute at arbitration is expensive and time-consuming. For this reason, appeal to arbitration is usually proceeded by a multi-step grievance procedure. These preliminary stages are a relatively swift and inexpensive means of resolving claims and have been successful in clearing up the vast majority of disputes arising under collective agreements. ${ }^{48}$ The processing and control of the grievance procedures often involve conflicting interests of all the parties involved - employer, union and employee alike. How these interests are balanced is therefore an important concern.

The union cannot allow the individual to proceed on his own because of its responsibility as exclusive bargaining agent. ${ }^{49}$ However, the union must also recognize that it would be improper to leave the grievance decision wholly with local of ficers who may act without knowledge of the earlier interpretations and intended meaning of the agreement. ${ }^{50}$ The practical solution has been to draft a grievance procedure which progresses through the hierarchy of the employer and union. Traditionally, the union's exclusive control over this grievance procedure is well recognized; however, individuals bringing actions alleging their union has breached its duty of fair representation may complicate this traditional method of settling disputes. Before examining the standards by which a union's conduct will be judged in these cases, several aspects of such claims should be noted.

\section{A. PROPER PARTIES}

It is generally accepted that employers will be made party to a fair representation action by the individual against the union. The rationale here is that it may be necessary to make an employer accept a resolution such as reinstatement, a new job assignment, or a change in seniority rankings. ${ }^{51}$ As a result, the employer will not be allowed to benefit from the union's breach of its duty. Conversely, it has been suggested that a failure to notify the employer and give him standing in the proceedings may amount to a denial of natural justice. ${ }^{52}$

While the employer may be made a party to the action, it has been stated that "the inquiry will not enter into the merits of employer action unless it is so intimately bound to the union's action to be improper to separate it." 53 Here, adjudication of the merits of the employer's actions will normally be deferred by the board to arbitration. In practice then, it is advisable that the grievor request the employer to be joined to the action.

48. Rayonier Canada (B.C.) Ltd. [1975] 2 Can. LRBR 196 (B.C.L.R.B.) at 203.

49. Occasionally, the union will permit the complainant to proceed on his own, but the cost of proceeding will be born by the employee and the decision will have no precedential value for/against the union in the future.

50. Haleyv. Canadian Airline Employees Assoc. (1981) 1 C.L.S. 6.2927 at 2929.

51. The leading case here is Imperial Tobacco [1975] 1 Can. LRBR 21.

52. Supra n. 2 Labour Law and Industrial Relations in Canada at 142.

53. Maffeiv. IBEW and Felec Services Inc. [1979] 1 C.L.S. 6.2632 at 2636. 


\section{B. EXHAUSTION OF INTERNAL UNION PROCEDURES}

In the United States, many jurisdictions have adopted the view that if there are any internal union procedures available to appeal the union's treatment of the grievance, they must be exhausted prior to instituting an action. ${ }^{54}$ Applying this exhaustion doctrine to the grievance procedure encourages the voluntary settlement of union-employer disputes. ${ }^{55}$

The C.L.R.B. has rejected this view and has not required the complainant to exhaust internal union appeal procedures before bringing a complaint alleging breach of the duty of fair representation. In the Lochner ${ }^{56}$ case it was held that because there is no legislative provision requiring the exhaustion doctrine to be applied, Parliament could not be said to have intended that non-union members may apply directly to the Board while union members must first prove they exhausted union channels. The court ruled that such a result, would be contrary to public policy for it would tend to discourage union membership. ${ }^{57}$

It is submitted the Lochner decision should not be followed. The issue in fair representation cases is whether there is relief available to the individual whose union has not fairly represented his claim against the employer. The exhaustion of remedies doctrine begs the question of whether the channels of communication through which the union and employer may reach agreement are being protected. If there is no requirement to use the grievance procedures provided for in the collective agreement, as Lochner suggests, then the policy of promoting voluntary settlement is frustrated..$^{58} \mathrm{By}$ implication then, it is suggested the concern for an efficient means to solve disputes overrides the policy argument expressed in Lochner, that requiring exhaustion in some cases, may discourage union membership. Nevertheless, the C.L.R.B. decision is strong support for the general proposition that a complainant need not exhaust internal union procedures before instituting a fair representation claim.

\section{TIMELINESS}

The requirement that a fair representation claim be asserted in a timely fashion is based on the necessity to accord the respondent union a fair hearing. Thus, a complaint filed some five years after the union's alleged breach of the fair representation duty was dismissed as being unreasonably delayed. ${ }^{59}$

54. Jeffery Ulman, “Exhaustion of Internal Union Appeals Procedures" supra n. 14 at 1090 91.

55. A.W. Blumrosen, “Legal Protection for Critical Job Interests" (1959) 13 Rutgers L.R. 631 at 647 .

56. Supran. 31.

57. Supran. 31 at 503.

58. A counter here could be that because of the very nature of the fair representation action, pursuing intra-union remedies is often a futile venture; for the American experience in this regard, see Naar supra n. 14 at 541.

59. Daleyv. A.T.U., Loc 1572, [1982] 2 Can. LRBR 392. 
Further, timely application has been required in order to maintain orderly conduct of the ongoing collective bargaining relationship: 60

It is universally recognized that the speedy resolution of outstanding disputes is of real importance in maintaining an amicable labour-management relationship.

Perhaps most importantly, it should be noted that the C.L.R.B. has refused to set out rigid guidelines as to how they will exercise their discretion under s. 89 of the Code with regard to time limits. Thus, unless there are exceptional circumstances or overriding public policy, the time limit will be measured in "months rather than years." 61

\section{REMEDIES}

Labour relations boards receive very broad powers under their respective governing Acts. ${ }^{62}$ Where a breach of duty of fair representation is found, usually the complainant should have had a right to have his claim arbitrated. To honour the integrity of the collective agreement, the Board will usually defer to the grievance arbitration procedure under the agreement in such cases. ${ }^{63}$

In some cases, the Board has shown a willingness to adjudicate the merits of a successful complainant's grievance and design an award accordingly. Thus where it was felt there was little chance that an arbitration board would award reinstatement, the Board has awarded a $\$ 1$ sum for nominal compensation. ${ }^{64}$ The Board has also exercised its remedial authority to allow an arbitrator (acceptable to all the parties) to determine whether the collective agreement has been breached. ${ }^{65}$ In a recent case, the Federal Court of Appeal held that the C.L.R.B. was within its jurisdiction in making the following "creative" award: that a member of the arbitration board be appointed by the employee and not by the union; that the employee have counsel of his choice; that the union pay all the employee's expenses and his share of the arbitration expense; and that the union pay part of any compensation ordered by the arbitration board. ${ }^{66}$

As discussed above, the Board can make the employer party to the action and therefore is able to structure an award apportioning the liability between the union and employer ${ }^{67}$ In a case where the union breached its duty of fair representation, but did not act in an arbitrary or discriminatory manner, the Board saw fit to refer the grievance back to the union (upon certain conditions) for review of its merits. ${ }^{68}$
60. Id. at 397.
61. Id.
62. E.g. Canada Labour Code s. 79; Ontario Labour Relations Act s. 89.
63. Supra n. 2 Labour Law and Industrial Relations in Canada at 142.
64. Joseph Pap and Int'l Union of Electrical, Radio and Machine Workers, Loc. 523 [1974] 1 Can. LRBR 74.
65. Shellington v. Imperial Tobacco Products (Ont.) [1974] OLRB Rep. 418.
66. Teamsters v. Massicotte(1981) 34 N.R. 611 (Fed. C.A.).
67. The American view is further refined: an award against a union may not include damages solely attributable to the employer's breach of contract, "but if any increases in those damages are caused by the union's refusal to process the grievance, [they] should not be charged to the employer'": White J. in Vaca v. Sipes supra n. 12 at 198.

68. Elliston v. U.S.W.A. supra n. 20. 


\section{THE UNION'S STANDARD OF CARE}

Canadian jurisdictions have not adopted a uniform standard by which the union's representation of the unit can be judged. While the provincial standards are couched in terms of what the union is prohibited from doing, the federal Code expresses the duty in a positive test. ${ }^{69}$ While the differences between the standards have been noted, ${ }^{70}$ it is clear that the language of the sections is sufficiently ambiguous to provide for widely varying standards.

To begin, certain matters with respect to the union's conduct have been generally accepted. First, the dominant view is that the fair representation duty will be gauged by a subjective test of what the union official believed to be true. ${ }^{71}$ By implication, the burden on the complainant is more onerous and the union will be more insulated from outside scrutiny.

Second, Canadian labour boards have consistently stated that in fair representation cases, what is at issue is the conduct of the trade union, not the merits of the grievance. ${ }^{72}$ Presumably, the rationale for this view is that evidence of the merits of the grievance will be introduced before an arbitration board if a breach of the duty is found and arbitration awarded. ${ }^{73}$ Further, if the "correctness" of the union's decision were reviewable, the resulting indecisiveness of union officials would be contrary to the policy of encouraging settlement short of arbitration. ${ }^{74}$

At least three interpretations of the fair representation duty have been developed. The first view emphasizes the union's exclusive bargaining status and gives a wide latitude of discretion to the union in its handling of grievances. Proponents of leaving the grievance procedure in the hands of the union ${ }^{75}$ base their argument on the need of both labour and management for a stable relationship in the work place. Establishing a single procedure through which labour disputes are funnelled, simplifies the grievance process for the employer. As exclusive representative for the employees, the union is able to ensure the employer that there will be no individual actions through other channels, such as the courts. From the union's point of view, exclusive control over the grievance process enhances its prestige as an effective represenative of the employee's interests. Additionally, as guardian of the collective interest, the union's

69. See Appendix A.

70. Maffei and Electrical Workers supra n. 53 at 2635; Haley and Canadian Airlines Employees Assoc. (1981) 1 C.L.S. 6.2927 at 2929.

71. Baird v. Teamsters Loc. 647 [1972] OLRB Rep. 240; Elliston v. U.S.W.A. [1982] 2 Can. LRBR 241; Ruby Chow and Overwaitea Foods [1981] 3 Can. LRBR 43; it should be noted however that the subjectivity of the test is tempered in that the mere will of the majority will not, by itself, justify predatory practices on the minority: Bukvich and Brewery Workers [1982] 1 Can. LRBR 422 at 431.

72. Erdelyiv. Machinists Local 2330 [1972] OLRB Rep. 844 at 845-46; Mellilo v. Sheet Metal Workers Loc. 540 [1977] I Can. LRBR 182 at 189; Leonard Murphy and IPGCU, Loc 482 [1977] 1 Can. LRBR 422; Samperiv. C.A.L.F.A.A. supra n. 45 at 214-15.

73. B. Adell, H. Arthurs et al., eds., Labour Relations Law(1981) at 450.

74. On settling grievances short of arbitration as a policy objective, see Melillo v. Sheet Metal Workers Int'l Ass'n supra n. 72 at 189.

75. Most notably A. Cox, "Rights under a Labour Agreement" (1955-56) 69 Harvard L.R. at 601 . 
authority would be undermined if an individual was successful in a claim which prejudiced the rights of other employees. In total, vesting the union with control of all grievances reduces the likelihood of unrest causing internal competition and discrimination that could be destructive to the workplace. ${ }^{76}$

A second view of the duty of fair representation suggests the law has been overly concerned with the needs of the employer and union, leaving the rights of the individual unprotected. Here it has been argued that allowing individual access to the grievance and arbitration process would serve to ensure that the terms of the collective agreement are complied with and can be achieved without undermining the collective decision regime. 77 The purpose of permitting individual processing is not merely to "strike a blow for individualism", 78 but to squarely address the problem of the union that refuses to take up the case. Giving the worker equal access to the dispute settlement machinery would seem to avoid the pitfalls of the present system, where giving the individual the right to compel the union to represent him of ten results in the unnecessary arbitration of unmeritorious claims.

A third possible interpretation of the fair representation standard suggests that the union will only be found to have breached its duty when its representation, or lack thereof, has impinged upon a "critical job interest" of the complainant. ${ }^{79}$ This view amounts to a mid-road alternative to the pro-individual and pro-union positions presented above. The doctrine recognizes the need to balance the interests between individual autonomy and union exclusivity. A higher degree of recognition of individual interest will prevail on matters of critical job interest.

The Board has not attempted to exhaustively define the concerns which will amount to a critical job interest. However, discharge, discipline and seniority have been suggested to be of sufficient interest, whereas minor job interests will include the occasional use of supervisors to do the bargaining unit work, ${ }^{80}$ isolated pay disputes, and minor disciplinary actions such as verbal warning. ${ }^{81}$

It is submitted that of the three formulations of the union's standard of care, only the critical job interest concept should be adopted. The first "pro-union" approach is undesirable because in practice it would be virtually impossible for the complainant to establish that the union acted in bad faith, or in a seriously negligent, arbitrary or discriminatory manner. Thus it would seem that the lax standard suggested in the following case would be going too far in favour of the union: ${ }^{82}$

We cannot say the duty of fair representation has absolutely no role during the arbitra-

tion process. There may be the extreme case where a union in bad faith merely puts on a

76. Supran. 47 at $272-3$.

77. B. Laskin, "Collective Bargaining and Individual Rights"' (1963) 6 Can. B.J. 278.

78. Id. at 287.

79. This doctrine was pioneered in the 1950's, see: A.W. Blumrosen, “Legal Protection for Critical Job Interest" supra n. 55; and has been endorsed by the C.L.R.B., see: Haley supra n. 50.

80. Beaudoin and Railway Carmen [1982] I Can. LRBR 197.

81. Haley supra n. 50 at 2928.

82. Samperi and CALFAA supran. 45 at 215. 
charade with employer collusion or the union representative or counsel appears inebriated ... The message is, however, that this Board will not, through the duty of fair representation, microscopically review union conduct during arbitration proceedings.

The second view, it would seem, has gone too far to the opposite pole in its emphasis of protecting individual rights. Giving individual employees independent access to the grievance-arbitration procedure would inevitably undermine the union's status as exclusive bargaining agent as provided for by statute. Here the crux of the matter is that the minority does not have an absolute right against negative consequences to their job security. ${ }^{83}$ The collective agreement is a contract made between the employer and the union, and the employee is bound by it. This agreement is not, however, "a bundle of individual contracts between the employer and employee." 84 Usually the interests of the individual and union coincide, but when they do not the union's obligation to act in the interests of the whole must take precedence. If the individual were given powers to control arbitration of the case, the expedience and inexpense of present grievance procedures would be lost, for each employee would be able to press his grievance despite a union decision that it would be better for all to settle short of arbitration. The remaining question then is how the exclusive bargaining agent's correlative duty to provide fair representation to all the members of the unit is to be determined.

With regard to the critical job interest doctrine, it is submitted the concept is useful, but incomplete as a standard to judge whether the fair representation duty has been breached. To illustrate, in a strict utilitarian application of the doctrine, if the union's decision does not generate a marginal advantage to the majority that outweighs the disadvantage to the minority, then it could be concluded that the union has breached its duty of fair representation. This approach would require the Board to judge the political correctness of the union's decision. The problem is that choosing which outcome is preferable "is a highly subjective decision, inevitably influenced by the inherent values, viewpoints and preferences of the decision-maker." 85 Clearly, the Board would not want to put itself in the position of substituting its own views for decisions duly considered by the union, simply because the grievance was of a serious nature. In the result, assessing whether a critical job interest has been affected is an important consideration, but additional factors must go into formulating the fair representation standard.

\section{THE CLOUTIER TEST}

In Cloutier and Cartage Union, ${ }^{86}$ the Canadian Labour Relations Board laid out a three part test to determine whether the fair representation duty has been breached. The Board must consider: one, the nature of the grievance; two, the degree of sophistication of the bargaining agent; three, the steps taken by the bargaining agent in processing the

83. Again, it should be noted that the aggrieved employee can have recourse to the courts on the basis of breach of contract, see note 3 .

84. McGavin Toastmaster Ltd. v. Ainscough(1975) 54 D.L.R. (3d) I (S.C.C.).

85. Bukvich and Brewery Workers [1982] 1 Can. LRBR 422 at 428.

86. [1981] 2 Can. LRBR 335. 
grievance. The Cloutier decision may well prove to be a landmark case in Canada; therefore, further examination of the three criteria is in order.

\section{A. NATURE OF THE GRIEVANCE}

Essentially, this stage incorporates the critical job interest analysis outlined above, to serve as a prerequisite to a successful fair representation claim. As previously stated, the Board has declined to formulate rigid guidelines as to what will constitute a critical job interest, but will likely include dismissal, discipline and seniority cases. ${ }^{87}$ To date, most fair representation actions in Canada and the United States ${ }^{88}$ have involved dismissal cases and therefore, this criterion can be expected to be satisfied in most cases. Further, boards have hastened to add that the alleged union misconduct directed to the employer "must be such as to produce actual, and not merely speculative prejudice" 89 to those employees.

\section{B. DEGREE OF SOPHISTICATION OF THE BARGAINING AGENT}

The degree of sophistication between unions varies greatly. Consequently, the services which may be reasonably expected from any given union will also vary. Because the employee has freedom to choose who his representative will be, ${ }^{90}$ it would be unfair for a bargaining unit member to expect a higher quality of representation than that which he had opted for. ${ }^{91}$ Thus, in judging the competence of union representatives, boards have been wary not to equate the representative's skills with those expected from lawyers. ${ }^{92}$ Accordingly, errors and mistakes made through ignorance, lack of training/experience, or lack of resources are to be expected - the scrutiny of which will vary according to how well equipped the union is financially and administratively.

Case law on union officers' neglect and incompetence is voluminous. In Ontario, the O.L.R.B. has been generally unwilling to find that union incompetence violates the union's duty of fair representation..$^{93}$ Quebec

87. See supra $\mathrm{n} .76$.

88. Under s. 136 of the Canada Labour Code, between June 1, 1978 and January 1, 1981, the Board received 79 complaints of which 46 arose because of a union's failure to proceed with a discharge (37) or disciplinary (9) grievance to the extent or in the matter of the individual would have preferred: see Haley supra n. 50 at 2928; similarly, in the United States the majority of duty of fair representation cases involve wrongful discharge: see Naar supra $\mathrm{n} .14$ at 536.

89. Manoni and Labourers' Int' ' [1982] 1 Can. LRBR 347 at 351.

90. E.g. sections 110 and 134 of the Canada Labour Code.

91. Samperi and CALFAA supra n. 45 at 212 ; although it should be recognized that this "choice" is of ten already decided in an established bargaining relationship.

92. E.g. Rutherford Dairy Ltd. [1972] OLRB Rep. 240 at 244; Haley supra n. 50 at 2931; note however that there is support for the proposition that a union should be held liable for the competence of the professional conduct of counsel: Holodnak v. Avco Corp. 381 F. Supp. 191 (D. Conn, 1974).

93. See Raymond E. Brown "the 'Arbitration', 'Discriminary', and 'Bad Faith' Tests under the Duty of Fair Representation in Ontario" (1982) 60 C.B.R. 412 at 438; a similarly restrictive view has been adopted by the B.C.L.R.B., see Morgan and Registered Nurses of British Columbia [1979] 1 CLRBR 441. 
has been the only jurisdiction to suggest the degree of negligence required for a union to be found to have breached its fair representation duty. ${ }^{94}$ This "seriously negligent" standard was found to have been breached where a union's failure to convene a meeting with regard to the complainant's grievance resulted in losing the claim. ${ }^{95}$

Under the federal jurisdiction, the C.L.R.B. has stated that scrutinizing the quality of representation of union officials during the grievance process is an "extreme application" of the fair representation duty. ${ }^{96}$ This conservative view has recently been followed in Samperi, where it was stated that the duty of fair representation is not to be construed as providing an avenue of appeal from arbitration decisions based upon the Board's judgment of the competence and performance of the union representatives. ${ }^{97}$ Nevertheless, it must be concluded that where the grievance is found to be of a serious nature and the union is a wellestablished, experienced organization, it will be subject to demanding scrutiny.$^{98}$

\section{STEPS TAKEN IN PROCESSING THE GRIEVANCE}

The final criterion to be assessed is the steps taken by the union in processing the grievance. Here the union's conduct will be judged against a backdrop of past practices and policies normally followed by the union in similar cases. Thus, if a grievance is of a serious nature, a total lack of representation usually amounts to a breach of the duty, ${ }^{99}$ unless the complainant was less than honest with the union in his representations concerning the grievance, ${ }^{100}$ or the union can prove the claim was not meritorious. ${ }^{101}$ In some cases the union has decided to "trade-off" interests of one group in exchange for some benefit conferred on the majority, or a favourable settlement of some other dispute. Here, it has been generally held that if the union's decision was one that could be rationally arrived at after an adequate investigation of the facts, the union will not be found to have breached its duty of fair representation..$^{102}$

With regard to complaints alleging discrimination, the B.C.L.R.B. has held that where a union adopts a policy which arbitrarily discriminates against one group of employees, there has been a breach of the fair representation duty, even if it was not motivated by bad faith. ${ }^{103}$ Other jurisdictions have adopted a narrower definition of what constitutes

\footnotetext{
94. See Appendix A.

95. Admin. de Pilotage des Laurentides G. Gagnon [1981] C.A. 431.

96. Haley (1980) 41 D.1. 295 at 302.

97. Samperi and C.A.L.F.A.A. supra n. 45 at 215 ; it is of further interest to note that while the characteristics of the complainant will not alter the duty imposed on the union, they may well serve to reduce the award where the complainant was fully aware of union procedures: Schumph and Int'l Assoc. of Machinists and Aerospace Workers (1981) 40 D.I. 123.

98. Laplante and Cartage Union (1981) 40 D.I. 235.

99. Ellistonv. U.S.W.A. supra n. 20; Massicottev. IBT(1980) 80 CLLC 16.014.

100. C.U.P.E. v. The Regional Municipality of Durham [1979] OLRB Rep. 1277.

101. Blumrosen supran. 55 at 658.

102. Bachiu v. Steelworkers Loc. 1005 [1976] 1 Can. LRBR 431.

103. Vancouver General Hospital [1978] 2 Can. LRBR 508.
} 
discrimination. Thus it has been held that where a union is merely implementing a non-discriminatory policy which affects a particular group, it will not be said to have breached its duty of fair representation, unless the policy is applied unequally amongst the members of the unit. ${ }^{104}$ Finally, as a practical matter, it would seem a complainant alleging collusion between the employer and union will have to meet an exacting standard of proof; ${ }^{105}$ whereas complaints alleging arbitrariness have a somewhat less exacting standard and therefore have been disproportionately successful. ${ }^{106}$

\section{CONCLUDING COMMENTS}

The role to be played by the union's fair representation duty in Canada is in its formulative stages. In the absence of effective alternative means of redress, the imposition of the duty was clearly needed to check inevitable examples of union misconduct. What remains unclear, however, is the extent to which individual rights can be asserted under the collective agreement.

The Canadian jurisdictions which have enacted legislation imposing a fair representation duty have left significant latitude for interpreting the standard by which union conduct is to be judged. How this malleable standard is to be applied poses difficult questions in both theory and in practice.

In theory, any credible interpretation of the duty must recognize a need to balance between the interest of the union as exclusive bargaining agent and the need to protect the individual employee from union misconduct. In practice, there is a need for commercial stability which is enhanced by promoting union exclusivity, and yet the concentration of power in the union must somehow be checked so as to ensure union sensitivity to the plight of the individual worker.

Founded on the principle of union exclusivity, it has been argued here that the statutory requirements of fair representation should be narrowly construed. The function of the union is first to resolve sometimes irreconcilable employee interests and then to act as a spokesman for the interests that carry the day. If the fair representation duty were broadly construed, the individual could manipulate the union to use the grievance procedure to obtain benefits which the employer had already refused to give. The relationship between the employer and union as exclusive bargaining agent would be undermined, and consequently, the entire collective bargaining process would be jeopardized. Put plainly, the duty of fair representation should not be interpreted to be a circuitous way of obtaining arbitration of a grievance that is without merit.

The benefits of a conservative application of the fair representation provisions are substantial. Protecting the channels used to resolve labour disputes should be a very real concern of Canadian labour boards. In the

104. Bukvich and Brewery Workers Local 304 [1982] 1 Can. LRBR 422 (O.L.R.B.); similar holding in Solly and CWC [1981] 2 Can. LRBR 245 (C.L.R.B.).

105. E.g. Scott, McConnell, Brock, et al. [1977] 1 Can. LRBR 497 (B.C.L.R.B.); Solly and CWC supra n. 98.

106. See R. Brown, supran. 93 at 440 . 
United States, where the fair representation duty has been given broad application, experience has shown that unions will act to protect themselves by taking unmeritorious cases to arbitration and as a result have undermined the relationship between employer and union, and clogged arbitral channels. ${ }^{107}$

Narrowly construing the union's duty of fair representation would also reduce unnecessary expense on dispute settlement. As parties to the collective agreement, it is the union and employer that pay for the arbitration machinery. For the employee, there is little downside risk to using a fair representation threat to force an arbitration he does not have to pay for. For the union wanting to protect itself against a fair representation action, it may be forced to spend its limited resources on a case it knows has little chance of success. As a further consequence, the union's ability to persuade management to concede claims which are well-founded will be hampered. For the employer, whose treatment of the employee is justified, the paradoxical result of having to retain counsel to arbitrate a dispute that the union implicitly or explicitly recognizes as unnecessary is both frustration and expense. Even if the employee volunteers to pay the union's side of the arbitration, the employer would still be left with the cost of having to defend an unmeritorious claim.

Assuming the American example was followed so that individuals could in effect compel arbitration, it must be questioned whether the result would be different anyway. If an arbitrator sensed that both employer and union believed the case to be without merit, it would seem very inviting to please the parties who paid for the arbitration and leave the militant employee without redress.

It should be made clear that the argument above stops well short of asserting that an individual employee has no remedy for unfair treatment at the hands of his union. Bad faith, discriminatory policies, arbitrariness and gross negligence by the union have not been tolerated by the labour boards and change is not suggested here. Additionally, it should be remembered that there are existing remedies available to the employee against his union in contract, tort and under human rights legislation.

Recent trends set by the Canadian labour boards are encouraging. The three part test delineated in Cloutier has already proven to be a significant step forward in developing a helpful analytical framework to guide employer, union and employee alike in fair representation cases. Recent decisions, particularly Manoni and Samperi, are to be commended for their conservative application of the union's fair representation duty.

Sustaining the integrity of the collective bargaining system will require the Canadian labour boards to give due deference to the decisions of union officials. This view necessarily requires that union representatives continue to make difficult decisions regarding serious claims. Here, it should be of some consolation to workers that history has clearly shown the union is best equipped to protect their interests. 


\section{APPENDIX A}

(i) Canada Labour Code: (enacted 1978)

s. 136.1. Where a trade union is the bargaining unit, the trade union and every representative of the trade union shall represent, fairly and without discrimination, all employees in the bargaining unit.

(ii) Alberta: (enacted 1980)

s. 138. No trade union and no person acting on behalf of a trade union shall deny an employee or former employee who is or was within the bargaining unit the right to be fairly represented by the trade union with respect to his rights under the collective agreement.

(iii) British Columbia: (enacted 1973)

s. 7(1). A trade union or council of trade unions shall not act in

a manner that is arbitrary, discriminatory or in bad faith in representing any of the employees in an appropriate bargaining unit, whether or not they are members of the trade union or of a constituent union of the council.

(2). An employers' organization shall not act in a manner that is arbitrary, discriminatory or in bad faith in representing any of the employers in the group appropriate for collective bargaining.

(iv) Ontario: (enacted 1960)

s. 68. A trade union, or council of trade unions so long as it continues to be entitled to represent employees in a bargaining unit, shall not act in a manner that is arbitrary, discriminatory or in bad faith in the representation of any of the employees in the unit, whether or not members of the trade union or of any constituent union of the council of trade unions, as the case may be.

(v) Quebec: (enacted 1977)

s. 47.2. A certified association shall not act in bad faith or in an arbitrary or discriminatory manner or show serious negligence in respect of employees comprised in a bargaining unit represented by it, whether or not they are members. 